\title{
Agenesis of Ductus Venosus: A Case Series
}

\author{
Bindiya Dhingra ${ }^{1} \cdot$ Adinarayan Makam $^{1}$
}

Received: 4 January 2020/Accepted: 27 February 2020/Published online: 23 March 2020

(C) The Author(s) 2020

\begin{abstract}
Ductus venosus agenesis is a rare anomaly which is significantly associated with cardiac, extracardiac and chromosomal anomalies. The prognosis depends on its association with other congenital abnormalities independent of the type of shunt. The aim of this study was to evaluate the ductus venosus in 2 nd trimester scans and to evaluate associated congenital malformations associated with agenesis of the ductus venosus and its feto-neonatal outcome. We performed a retrospective study for a 5 year period from November 2015 to November 2019. Of the 8 cases seen, $2(25 \%)$ had an intrahepatic shunt and $6(75 \%)$ presented with extrahepatic umbilical venous drainage. Agenesis of ductus venosus was associated in 5 cases (62\%) with cardiac abnormalities, 6 cases (75\%) with extracardiac anomalies and $3(37 \%)$ cases with chromosomal abnormality. Our study showed poorer outcome in fetuses associated with both cardiac and extracardiac anomalies accounting for $75 \%$ of all cases whereas intrahepatic type with mild cardiomegaly had favourable pregnancy outcome. Agenesis of ductus venosus is significantly associated with fetal cardiac and extracardiac abnormalities independent of the type of umbilical venous drainage. Extrahepatic umbilical venous drainage even if isolated has the significant risk of congestive heart failure, hydrops and/or intrahepatic portal venous system anomalies. The intrahepatic type has better prognosis if associated with no or minor abnormality.
\end{abstract}

Bindiya Dhingra

bindiyadhingra237@gmail.com

1 ADI Advanced Centre for Fetal Care, Sparsh Hospital, Yeshwanthpur, Bangalore, India
Keywords Ductus venosus agenesis · 2nd trimester · Malformations · Doppler · Outcome

\section{Introduction}

The human fetal circulation depends on three physiological shunts: the ductus arteriosus, the foramen ovale and the ductus venosus (DV), making the fetal circulation a flexible and adaptive system throughout intrauterine life [1]. Sonographic investigation of the fetal venous system has developed rapidly since its introduction in the mid-1980s. The main function of the fetal venous system is to deliver blood rich with oxygen and nutrients from the placenta to the fetal heart. The DV plays a critical role in this important function.

The ductus venosus is an important fetal vascular structure that connects the intra-abdominal umbilical vein to the inferior vena cava at its inlet to the heart. The portocaval pressure gradient causes well-oxygenated blood in the DV to accelerate towards the inferior vena cava enabling its preferential streaming to the cephalic and coronary circulation [1]. The balance of umbilical venous flow enters the portal circulation and streams predominantly to the left lobe of the liver. The DV, therefore, plays a key role in increasing the shunt of oxygenated blood to the heart and decreasing placental return during hypoxemia and hypovolemia [2, 3]. Normally at 20 weeks gestation, about $30 \%$ of blood is shunted through the DV, while at 30 weeks about $20 \%$ of blood is shunted $[2,4,5]$. This reduction in the mean fraction from 30 to $20 \%$ suggests fetal liver priority in circulation.

Absence of ductus venosus (ADV) in the fetus was reported in the nineteenth century [6], and with the widespread use of ultrasound techniques and their improvement 
over the years, a more careful examination of the fetal circulation, particularly the umbilical and portal venous malformations, can now be performed prenatally.

Agenesis of the DV results from failure to form the "critical anastomosis', that is, no connection is established between the umbilical vein and DV. When the DV is absent, the umbilical blood flows from the umbilical vein through an aberrant vessel that may be extrahepatic, bypassing the liver, or intrahepatic, via the portal venous system [7-9].

Two different routes for umbilical venous return have been described in fetuses with ADV:

1. Extrahepatic umbilical venous drainage - the umbilical vein shunts blood directly to the iliac vein, the inferior vena cava, the renal vein, the right atrium or, exceptionally, the left atrium or the coronary sinus [10-13].

2. Intrahepatic umbilical venous drainage - the umbilical vein connects through the portal sinus to hepatic sinusoids without giving rise to the DV [2, 11, 14-16].

DV agenesis is associated with congenital morphological abnormalities in approximately $65 \%$ of cases and with cytogenetic abnormalities in $17 \%[16,17]$. In $24-65 \%$ of cases, it is associated with cardiac, extracardiac (single umbilical artery being the most common) and chromosomal anomalies, Noonan syndrome, agenesis of the portal vein in as many as $50 \%$ of the cases [8], hydrops and generalized edema in $33-52 \%$ of the cases [11, 17].

Prognosis depends on the location of the umbilical drainage site and associated malformations with previous reports clearly demonstrating high incidences of congestive heart failure and agenesis of the portal venous system in ADV with extrahepatic umbilical venous drainage [11-13]. Fetuses with an intrahepatic shunt are rarely associated with any malformation and hence, a better outcome is expected in cases without liver bypass [13, 17, 18]. DV agenesis presents as an isolated finding in only $35-59 \%$ of cases. In such cases, however, 80-100\% have a normal outcome [11, 19].

\section{Aim and Objective}

1. To evaluate ductus venosus in 2 nd trimester scans.

2. To evaluate associated congenital malformations associated with agenesis of ductus venosus and the fetoneonatal outcome.

\section{Materials and Methods}

This was a retrospective study from November 2014 to November 2019. 8 cases of agenesis of the ductus venosus were found.

\section{Inclusion Criteria Were}

All singleton pregnancies (low, high risk and referred) in the 2 nd trimester.

\section{Observations and Results}

Fig. 1 shows number of cases diagnosed in our centre in the last 5 years.

$25 \%(2 / 8)$ of the fetuses were reported with the Intrahepatic drainage while $75 \%$ were reported with extrahepatic drainage (Fig. 2). In extrahepatic shunts, in most of the cases, the umbilical vein was drained into the inferior vena cava (Figs. 3, 4, 5, 6).

As shown in, Table 1, 1 fetus was terminated because of associated malformations. In the second case, mild cardiomegaly was found and the fetus was delivered at term.

Table 2, showing findings and outcomes in fetuses with ADV and extrahepatic venous drainage.

\section{Discussion}

This study identified a total of 8 cases of DV agenesis, out of which $2(25 \%)$ fetuses had an intrahepatic shunt and 6 (75\%) had an extrahepatic shunt. Intrahepatic umbilical venous drainage has been reported rarely, although they may occur more frequently compared to extrahepatic shunt. The diagnosis is often missed as it requires color flow mapping of the fetal portal circulation. On the other hand, extrahepatic drainage is easy to assess and can be detected on grey scale by the abnormal course of the intra-abdominal umbilical vein. A similar study was conducted by Kiserud et al. [2], where diagnosis of agenesis of DV with intrahepatic umbilical venous drainage was not a common finding. Irrespective of the type of shunt, agenesis of DV is significantly associated with cardiac, extra cardiac and chromosomal anomalies and syndromic diseases. In our study, there was a significant association with complex fetal malformation syndromes, cardiac defects and hydrops. Fetus with ADV may be hypoxic because of obstruction of placental venous return resulting in placental edema and impaired gas exchange. This reduces maternofetal transfer of proteins causing decrease in fetal plasma protein levels and causing development of hydrops. This study showed that cases of DV agenesis associated with fetal malformations comprising both cardiac and extracardiac malformations $(75 \%)$ showed poorer outcome with higher proportion of no survivors. According to the study of Siven et al. [7], three of the four previously reported cases showed associated malformations and 2 of them suffered from portal congestion and hydrops. Among our 8 


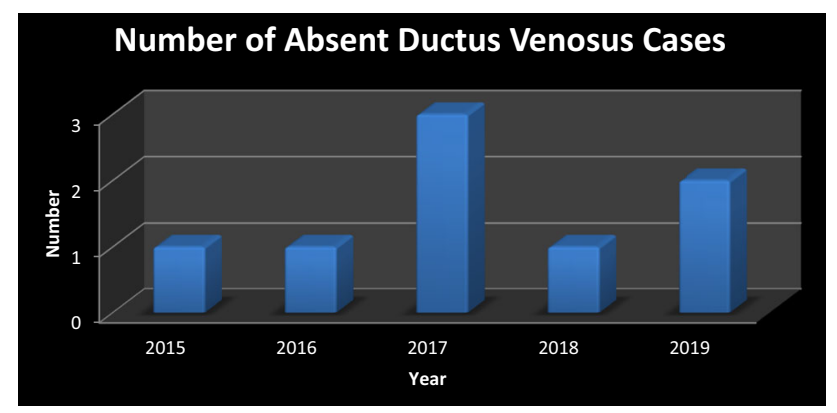

Fig. 1 Number of cases of absent ductus venosus

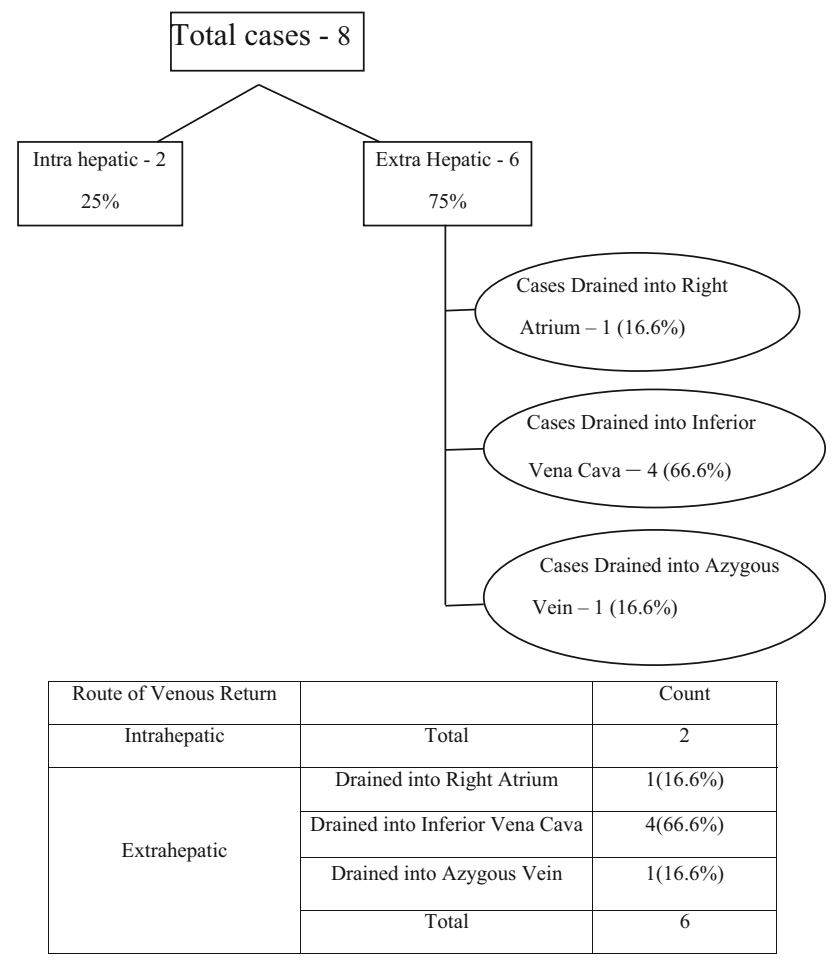

Fig. 2 Routes of venous return

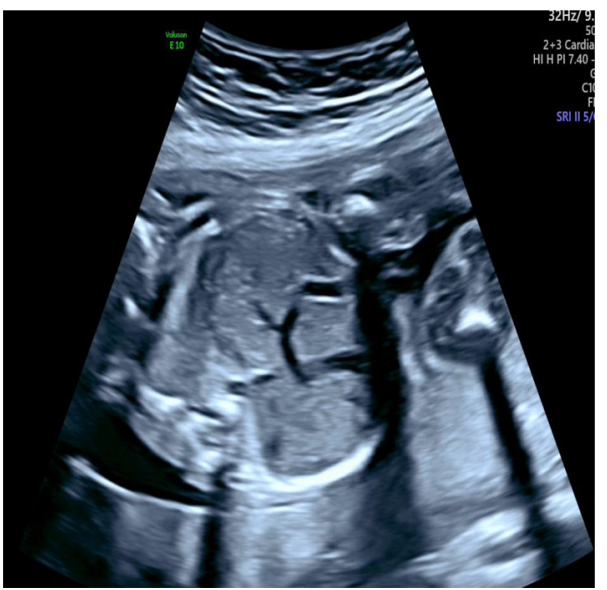

Fig. 3 Intrahepatic shunt with normal portal system

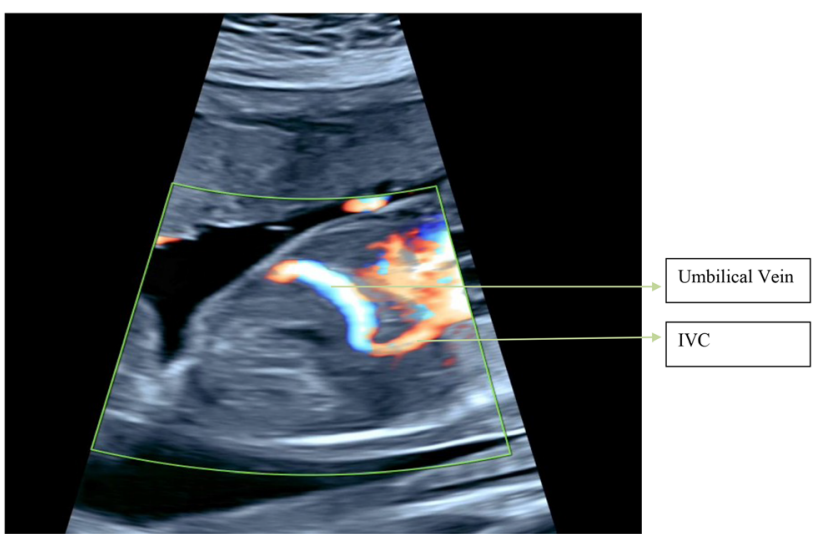

Fig. 4 Extrahepatic shunt: umbilical vein draining directly into inferior vena cava (IVC)

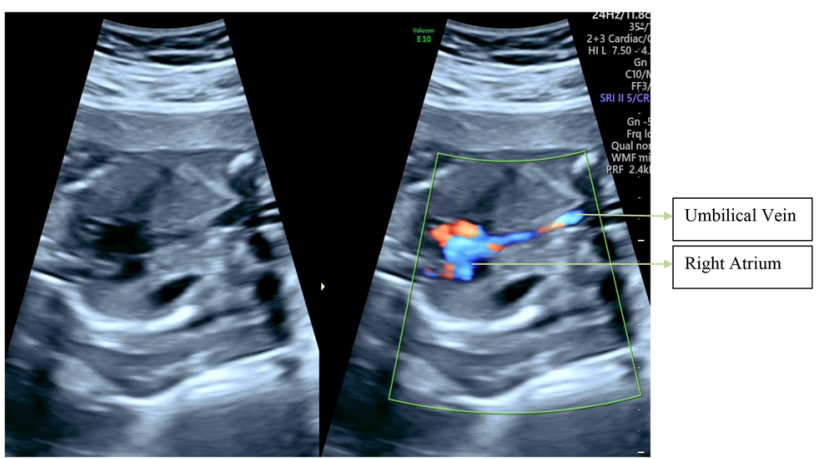

Fig. 5 Extrahepatic shunt: umbilical vein draining directly into right atrium

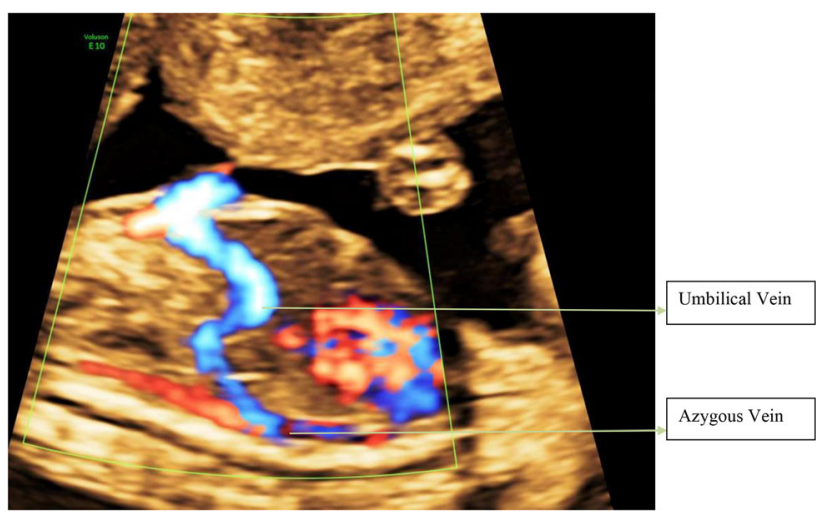

Fig. 6 Extrahepatic shunt: umbilical vein draining directly into azygous vein

cases, 3 (37\%) fetuses showed hydropic changes, 5 (62\%) showed severe malformations in the cardiovascular system which included tetralogy of Fallot, pulmonary artery stenosis, ventricular septal defects (VSD), common arterial trunk, double outlet right ventricle and right atrial defect. In the central nervous system, there were $4(50 \%)$ cases including vermian hypoplasia, corpus callosum hypoplasia, cerebellar hypoplasia, choroid plexus cyst, large dorsal cyst 
Table 1 Associated anomalies with sonographic findings and outcome in 2 fetuses with the absence of DV and intrahepatic venous drainage

\begin{tabular}{|c|c|c|c|c|c|c|}
\hline Case & Associated anomaly & $\begin{array}{l}\text { Gestational } \\
\text { age }\end{array}$ & $\begin{array}{l}\text { Hydropic } \\
\text { changes }\end{array}$ & Additional sonographic findings & Karyotype & Outcome \\
\hline 1 & $\begin{array}{l}\text { Malformation } \\
\text { syndrome }\end{array}$ & 22 & $\begin{array}{l}\text { Ascitis } \\
\text { Polyhydraminos } \\
\text { Placentomegaly }\end{array}$ & $\begin{array}{l}\text { Vermian hypoplasia } \\
\text { TOF with pulmonary artery } \\
\text { senosis }\end{array}$ & $\begin{array}{l}\text { Not } \\
\quad \text { assessed }\end{array}$ & $\begin{array}{c}\text { Termination of } \\
\text { pregnancy }\end{array}$ \\
\hline 2 & None & 18 & None & Mild cardiomegaly & $46, \mathrm{XX}$ & Delivered at term \\
\hline
\end{tabular}

Table 2 Associated anomalies with sonographic findings and outcome in 6 fetuses with the absence of DV and extrahepatic venous drainage

\begin{tabular}{|c|c|c|c|c|c|c|c|}
\hline Case & Associated anomaly & $\begin{array}{l}\text { Gestational } \\
\text { age }\end{array}$ & $\begin{array}{l}\text { UV } \\
\text { drainage }\end{array}$ & $\begin{array}{l}\text { Hydropic } \\
\text { changes }\end{array}$ & $\begin{array}{l}\text { Additional } \\
\text { sonographic findings }\end{array}$ & Karyotype & Outcome \\
\hline 11 & $\begin{array}{l}\text { Chromosomal anomaly and } \\
\text { malformation syndrome }\end{array}$ & $19+5$ weeks & UV-IVC & Ascitis & $\begin{array}{l}\text { Corpus callosum } \\
\text { hypoplasia } \\
\text { Bilateral choroid } \\
\text { plexus cyst } \\
\text { Bilateral } \\
\text { ventriculomegaly } \\
\text { Mild pericardial } \\
\text { effusion }\end{array}$ & 47XX, T18 & $\begin{array}{l}\text { Termination of } \\
\text { pregnancy }\end{array}$ \\
\hline 22 & Malformation syndrome & $20+4$ weeks & UV-RA & Polyhydraminos & $\begin{array}{l}\text { Large dorsal cyst in } \\
\text { fetal brain } \\
\text { Bilateral mild } \\
\text { ventricylomegaly } \\
\text { Mild cardiomegaly }\end{array}$ & $46, \mathrm{XY}$ & $\begin{array}{c}\text { Delivered at } \\
33 \text { weeks }\end{array}$ \\
\hline 33 & Malformation syndrome & $21+4$ weeks & UV-IVC & None & $\begin{array}{l}\text { Tetralogy of fallot } \\
\text { Pulmonary stenosis } \\
\text { Single umbilical } \\
\text { artery }\end{array}$ & $\begin{array}{l}\text { Not } \\
\quad \text { assessed }\end{array}$ & $\begin{array}{l}\text { Delivered at } \\
\text { term }\end{array}$ \\
\hline 44 & $\begin{array}{l}\text { Chromosomal anomaly and } \\
\text { malformation syndrome }\end{array}$ & 20 weeks & UV-IVC & None & $\begin{array}{l}\text { Common arterial } \\
\text { trunk (type } 3 \text { ) } \\
\text { Mild truncal } \\
\quad \text { regurgitation } \\
\text { VSD } \\
\text { Persistent left superior } \\
\text { vena cava }\end{array}$ & $\begin{array}{l}\text { 46, XY, } \\
\quad \text { Del22q17 }\end{array}$ & $\begin{array}{l}\text { Termination of } \\
\text { pregnancy }\end{array}$ \\
\hline 5 & $\begin{array}{l}\text { Chromosomal anomaly and } \\
\text { malformation syndrome }\end{array}$ & $18+1$ weeks & $\begin{array}{l}\text { UV- } \\
\text { azygous } \\
\text { vein }\end{array}$ & None & $\begin{array}{l}\text { Cerebellar hypoplasia } \\
\text { Right paramedian } \\
\text { cleft lip and palate } \\
\text { Small VSD, right } \\
\text { arterial defect } \\
\text { Bilateral severe renal } \\
\text { pelvic dilatation }\end{array}$ & $47 \mathrm{XX}, \mathrm{T} 21$ & $\begin{array}{l}\text { Termination of } \\
\text { pregnancy }\end{array}$ \\
\hline 66 & Malformation syndrome & $22+3$ weeks & UV-IVC & None & $\begin{array}{l}\text { DORV of TGA type } \\
\text { Small left ventricle, } \\
\text { mitral atresia }\end{array}$ & $\begin{array}{l}\text { Not } \\
\quad \text { assessed }\end{array}$ & No follow up \\
\hline
\end{tabular}

and ventriculomegaly, and $3(37 \%)$ cases were detected with chromosomal abnormalities. Other vascular anomalies like single umbilical artery and persistent left superior vena cava were also diagnosed along with facial anomalies.

The diagnosis of DV agenesis becomes easier if it is associated with other findings, mainly cardiomegaly and other vascular abnormalities and therefore, evaluation of ductus venosus becomes important in the presence of any other vascular abnormality including a single umbilical artery.

Furthermore, the current study observed that the prognosis of DV agenesis gets aggravated when there is isolated 
intrahepatic umbilical venous drainage with no or minor abnormality. 2 cases were studied in the course of the study where 1 case was isolated DV agenesis with mild cardiomegaly and had good pregnancy outcome whereas the 2nd case was associated with malformation that resulted in the termination of the pregnancy. Similarly, according to the study of Berg et al. [17], it was found that all 13 fetuses with isolated DV agenesis without liver bypass survived, and none had long-term sequelae attributable to the agenesis of DV. Similar to our study, DV agenesis with extrahepatic umbilical venous drainage was associated with fetal malformations, aneuploidies and highoutput cardiac failure due to chronic volume overload of the central venous system in the study of Contratti et al. [11].

The current findings suggested that the prognosis of DV agenesis with extrahepatic umbilical venous drainage seems to depend mainly on the presence and extent of fetal congestive heart failure in the absence of additional fetal anomalies. This is similar to the study of Berg et al. [17], where twenty-nine fetuses with isolated DV agenesis and liver bypass were identified, ten of which subsequently died (seven intrauterine deaths with cardiomegaly and/or hydrops, two perinatal deaths of fetuses with congestive heart failure that were prematurely delivered, one sudden infant death). Fetuses with isolated intrahepatic drainage with no or minor malformation have better pregnancy outcome compared to fetuses with extrahepatic shunt. Fetuses with agenesis of DV that survive, suffer from long term postnatal sequelae including congestive heart failure, pulmonary edema, focal nodular hyperplasia and hepatic tumors.

\section{Conclusion}

Agenesis of Ductus Venosus is a rare condition and is significantly associated with fetal co-morbidities. In case of extrahepatic umbilical venous drainage, even if isolated, the risk of congestive heart failure (or hydrops) and/or intrahepatic portal venous system anomalies is significant, whereas DV agenesis with an intrahepatic shunt has better prognosis if associated with no or minor malformation.

The DV is not examined routinely in the 2nd trimester screening and hence, can be missed if it is an isolated finding. This study reconfirms the need for detailed vascular delineation and reiterates points for counseling.

\section{Compliance with Ethical Standards}

Conflict of interest The authors declare that they have no conflict of interest.
Open Access This article is licensed under a Creative Commons Attribution 4.0 International License, which permits use, sharing, adaptation, distribution and reproduction in any medium or format, as long as you give appropriate credit to the original author(s) and the source, provide a link to the Creative Commons licence, and indicate if changes were made. The images or other third party material in this article are included in the article's Creative Commons licence, unless indicated otherwise in a credit line to the material. If material is not included in the article's Creative Commons licence and your intended use is not permitted by statutory regulation or exceeds the permitted use, you will need to obtain permission directly from the copyright holder. To view a copy of this licence, visit http://creativecommons. org/licenses/by/4.0/.

\section{References}

1. Kiserud T, Acharya G. The fetal circulation. Prenat Diagn. 2004;24:1049-59.

2. Kiserud T, Rasmussen S, Skulstad S. Blood flow and the degree of shunting through the ductus venosus in the human fetus. Am J Obstet Gynecol. 2000;182:147-53.

3. Tchirikov M, Eisermann K, Rybakowski C, Schroder HJ. Doppler ultrasound evaluation of ductus venosus blood flow during acute hypoxemia in fetal lambs. Ultrasound Obstet Gynecol. 1998;11:426-31.

4. Bellotti M, Pennati G, De Gasperi C, Battaglia FC, Ferrazzi E. Role of ductus venosus in distribution of umbilical blood flow in human fetuses during second half of pregnancy. Am J Physiol Heart Circ Physiol. 2000;279:H1256-63.

5. Kiserud T. Venous flow in intrauterine growth restriction and cardiac decompensation. In: Yagel S, Silverman NH, Gembruch U, editors. Fetal cardiology. 2nd ed. New York: Informa Healthcare; 2009. p. 547-60.

6. Paltauf R. Ein Fall von Mangel des ductus venosus Arantii. Wien Klin Wochenschr. 1888;7:127-31.

7. Siven M, Ley D, Hägerstrand I, Svenningsen N. Agenesis of the ductus venosus and its correlation to hydrops fetalis and the fetal hepatic circulation: case reports and review of the literature. Ped Pathol Lab Med. 1995;15:39-50.

8. Yagel S, Kivilevitch Z, Cohen SM, Valsky DV, Messing B, Shen $\mathrm{O}$, et al. The fetal venous system, Part II: ultrasound evaluation of the fetus with congenital venous system malformation or developing circulatory compromise. Ultrasound Obstet Gynecol. 2010;36:93-111.

9. Shen O, Valsky DV, Messing B, Cohen SM, Lipschuetz M, Yagel $\mathrm{S}$. Shunt diameter in agenesis of the ductus venosus with extrahepatic portosystemic shunt impacts on prognosis. Ultrasound Obstet Gynecol. 2011;37:184-90.

10. Perles Z, Nir A, Nadjari M, Ergaz Z, Raas-Rothschild A, Rein AJ. Absent ductus venosus in the fetus: review of the literature and first report of direct umbilical venous drainage to the coronary sinus. Fetal Diagn Ther. 2003;18:247-51.

11. Contratti G, Banzi C, Ghi T, Perolo A, Pilu G, Visentin A. Absence of the ductus venosus: report of 10 new cases and review of the literature. Ultrasound Obstet Gynecol. 2001;18:605-9.

12. Sau A, Sharland G, Simpson J. Agenesis of the ductus venosus associated with direct umbilical venous return into the heartcase series and review of literature. Prenat Diagn. 2004;24:418-23.

13. Jaeggi ET, Fouron JC, Hornberger LK, Proulx F, Oberhansli I, Yoo SJ, Fermont L. Agenesis of the ductus venosus that is associated with extrahepatic umbilical vein drainage: prenatal features and clinical outcome. Am J Obstet Gynecol. 2002;187:1031-7. 
14. Gembruch U, Baschat AA, Caliebe A, Gortner L. Prenatal diagnosis of ductus venosus agenesis: a report of two cases and review of the literature. Ultrasound Obstet Gynecol. 1998;11:185-9.

15. Achiron R, Hegesh J, Yagel S, Lipitz S, Cohen SB, Rotstein Z. Abnormalities of the fetal central veins and umbilico-portal system: prenatal ultrasonographic diagnosis and proposed classification. Ultrasound Obstet Gynecol. 2000;16:539-48.

16. Volpe P, Marasini M, Caruso G, Lituania M, Marzullo A, Volpe G, Gentile M. Prenatal diagnosis of ductus venosus agenesis and its association with cytogenetic/congenital anomalies. Prenat Diagn. 2002;22:995-1000.

17. Berg C, Kamil D, Geipel A, Kohl T, Knopfle G, Hansmann M, Gembruch U. Absence of ductus venosus-importance of umbilical venous drainage site. Ultrasound Obstet Gynecol. 2006;28(3):275-81.

18. Gorincour G, Droulle P, Guibaud L. Prenatal diagnosis of umbilicoportosystemic shunts: report of 11 cases and review of the literature. AJR Am J Roentgenol. 2005;184:163-8.

19. Hoppen T, Hofstaetter C, Plath H, Kau N, Bartmann P. Agenesis of the ductus venosus and its correlation to hydrops fetalis. J Perinat Med. 2000;28:69-73.

Publisher's Note Springer Nature remains neutral with regard to jurisdictional claims in published maps and institutional affiliations. 